\title{
Research on the Intrinsic Value Orientation of Higher Education Under the Background of Market Economy
}

\author{
Yan Kui ${ }^{1}$ \\ 1 Graduate School of WHUT, Wuhan 430070, China
}

Key words: Market Economy, Higher Education, Value Orientation

\begin{abstract}
Under the background of market economy, the marketization trend of colleges and universities guides the focus and concern of the society. Therefore, it is an important and difficult task to establish the intrinsic value of colleges and universities to play an important role in the cultivation of students and the development of society. From the epistemological value, political value and perfectionism value of higher education are analyzed. The education system should establish perfectionism value of higher education, lead knowledge exploration and political development, all aspects of cultivating talents for the socialist modernization of our country.
\end{abstract}

\section{Higher education under the background of market economy}

The marketization of higher education has been constantly challenged by the society, but the increasing frequency of brand effect, performance evaluation, incentive mechanism, cost benefit and economic concept in higher education is higher, and is gradually accepted. Although some scholars believe that the "market" is just a popular concept and its figurative meaning is higher than the practical significance, this kind of phenomenon also reflects the market economy to the higher education of a kind of penetration. Academic Capitalism and Entrepreneurship University have been a trend.

Market is not only the mechanism of commodity exchange, the social and economic system of resource allocation, but also a kind of value concept and system. It's the public rationality and value idea of the social members in the view of commodity. Since the industrial revolution, the concept of commodity has gradually influenced people's values and rational development, and the market mechanism has been expanding in all fields of society. Karl Polanyi held a thought that the industrial revolution has realized the most basic production factors of the human production and life, namely the labor force and the land market, which has promoted the transformation of the human development history ${ }^{[3]}$. With the continuous development of market economy, the market appears substantial expansion, namely commodities allocation of resources to two-way definition of commodity markets and the expansion of public reason, citizens of the goods market allocation. The concept of market economy impact on the social and political fields deeper and deeper. The assumption of rational economic man is gradually weakened, and people based on emotion and people based on justice are gradually replaced by the interests of the people. More and more social members are dealing with the social problems in the way of "economic" logical thinking. The trend of deep market society is becoming more and more obvious.

How to define the higher education in the context of "deep market society"? Different scholars hold different views. Economists think that the higher education market should be further strengthened, and the management mechanism and teaching system should be adjusted and reform based on the market operation mechanism, then gradually changing the relationship between universities and other social organizations. The goal is to transform the university into a business subject. The educationists and humanists are not optimistic about the development trend of universities. They are more likely to associate the marketization with utility. They worry that the market will affect the value of Higher Education and think that marketization is the inhuman culture of higher education, which will inevitably lead to the development of the objective of the utilitarian, the destruction of the university's eternal spirit. What is the intrinsic value of the higher education in the nature of the debate over the higher education? In the context of market economy, how to adhere to this value? The reason why scholars argue is that there is a difference between the attitudes 
towards market and society. Albert Hirshman, an economist, has put forward a question that is worth pondering. How does the intellectual elite know the market economy? Scholars who support the educational market include classical economists and Neo liberal scholars, such as Bentham, Mill, Hayek, Freedman, and so on. They think that the market economy can provide the idea of innovation and freedom for the development of education, improve the openness of the education system. Against the commercialization of education scholars include Marx doctrine and Communitarianism scholars, such as Marx, Kant, Habermas, Mike, Sandel, etc. They think that the marketization is not innovation but impetuous, not free but chaotic, and even cause education chaos ${ }^{[4]}$. Understanding the differences of market economy is an important prerequisite for the definition of the nature of higher education market, and to understand the difference should return to the concept of value. What is value? What is the intrinsic value? What is the intrinsic value of higher education? What is the impact of market economy on the intrinsic value of higher education? The understanding of these problems is related to the origin of human existence and development. Exploration of the value of education has also been regarded as "the last and best hope for mankind" by Lincoln.

\section{Analysis on the intrinsic value of higher education}

\subsection{Value and intrinsic value}

Value is the most complex and profound concept of ethics. Aristotle and Platon in ancient Greece, deeply discussed the issue of human nature and demonstrated the meaning of life, the value of happiness. Then the hedonism of Epicurus, the utilitarianism of Bentham, and the deontology of Kant continue to develop and have gradually formed the Value Theory of Western Color. The Confucian School represented by Confucius in China demonstrated the value of "benevolence" and "good". "The way of the great learning involves manifesting virtue, loving the people, and abiding by the highest good." Confucius theory has gradually developed into a traditional theoretical system in China.

The Intrinsic Value is an important part of Value. It refers to the value of the existence of the value without the use of other values, but also known as the inherent value or eternal value. Value and intrinsic value are the most basic and complex problem in human society. What possesses the intrinsic value? What is the intrinsic value? People are constantly exploring. From a fundamental perspective, the two issues involved in the core are the existence and existing form of intrinsic value. Prior to twentieth Century, scholars generally believed that the intrinsic property is an inherent property of the material. But G. E. Moore thought that the intrinsic value was different from the inherent property of materials. Some scholars believe that there is no intrinsic value. For example, Hobbes believes that good and evil are the emotion or view of social members, and they are not inherent. Whether the intrinsic value is stable is another controversial issue. Scholars who think that the intrinsic value exists also believe that the intrinsic value is stable. The pragmatists think that the intrinsic value is not eternal. For example, Dewey thinks the world is changing, and it's wrong to perceive a value as the same forever. Though the Pragmatism holds that intrinsic value is variable, In the special historical period, the intrinsic value of the society is certain. The value is also known as the human value, which is the direction of social progress.

\subsection{The intrinsic value of Higher Education}

The intrinsic value of higher education is the fundamental purpose of the development of higher education, and it is the important meaning of higher education in society. Based on the analysis of the educational value of ancient scholars and Brubaker's consideration on the knowledge value and practical value of higher education, this study considers and analyzes the intrinsic value of higher education from three aspects.

\subsubsection{Epistemological value}

The truth is the value of higher education, Aristotle once said: "I love my teacher, but I love truth more". Knowledge itself is a kind of intrinsic value, which is not because of the practicality of knowledge, but also because knowledge is valuable in itself. Brubaker believes that 
higher education in the pursuit of knowledge is "profound knowledge", and demonstrates what is "profound knowledge", and he believes that the trivial knowledge closely related to life is practical, but does not belong to the category of profound knowledge, should be excluded from the University education; The commercialization tendency of technical knowledge is serious, the social organization will form knowledge $\mathrm{R} \& \mathrm{D}$ institutions in the pursuit of economic interests, these institutions are for the purpose of economic interests, this knowledge has changed in essence, marketization knowledge is also not profound knowledge; the basic theoretical knowledge including natural, social and cultural aspects of these, these basic theoretical knowledge and commercialization in equilibrium, and has intrinsic value, so only the basic theoretical knowledge is the core of university education and the profound knowledge of higher education. Knowledge value is not comparable, and can't be quantified or measured with economic value, some knowledge bring great economic value can't be thought that this knowledge is more valuable than others, there is no difference between different knowledge. The ideal state of higher education from the perspective of epistemology value is the academic pursuit activity of people who take the development of knowledge and truth as the highest goal. The management mechanism of ideal university is different from the reality, the motivation of teachers' teaching is not material, but a kind of spirit power, they rely on their interest in knowledge discovery more than the external pressure to realize students' progress and their own development, thus the extra incentive mechanism to supervise the teachers is no longer necessary. Compensation and reputation are not what they are concerned about, and they will not affect their motivation and actions to discover knowledge. The logic of the University and the marketization higher education is completely opposite, but this is only an ideal state, not exist in reality. There have been university similar to this status in history, such as Jixia Academy, Berlin University, but they all were not kept for a long time. The development of modern university and this ideal state is more and more far, scholar Weber once said that the people who take the understanding of truth as a life goal will pay a heavy price, a lot of people can't stand the pressure and turn to compromise to material, interests and market, especially under the environment where the development of university more and more depend on funding and equipment, this kind of compromise is more obvious.

\subsubsection{Tractatus Politicus value}

Brubaker demonstrated the practical value of higher education and analyzed the value of universities from the perspective of Tractatus Politicus, namely explored actual utility of university. The university from the perspective of Tractatus Politicus is given to other targets in addition to the cognition of truth to pursuit some material things, "all the great education philosophers view education as a branch of political ". Compared to the immutability of knowledge value, the stage of political value is obvious. The political value of higher education is determined by the realistic condition and political goals at the time, the purpose of higher education is serving for the war in time of war, while at peacetime is to cultivate high-qualified talents for development of social political economy. At the present stage, high level and research-based university is the construction goal of our country, which serving for the development of national innovation system. Economy is an important part of the comprehensive national strength, so the contemporary university to a great extent is serving for the economic development. The political value of higher education advocated practicability and applicability of education, which improved the vitality of education system and promoted the improvement of students' practical ability, but also reduced the value ideas which higher education pursued. Education has to serve for realistic demand, such as employment, earnings and international competition. These realistic demands some are proper and noble, while some is vulgar and superficial, they need be verified by ethics. If social demands lack effective inspection, the value of higher education will be transitory so that it can't support for the sustainable development of society. The change pragmatists emphasized is not necessarily for the better. If the goal of political development is to realize the common well-being of all mankind, the inner value of higher education in political terms is also good and promotes the development of the overall welfare of mankind. However, whether the development of human society is only the pursuit of happiness is also a controversial philosophical question. Aristotle and Platon view happiness as the highest good 
of human, but Kant opposed to the view think virtue and happiness are different in nature, morality can achieve happiness but happiness can't cultivate morality, sometimes corrupt it. Morality is related to human dignity, the reason why people is lofty not because it obtained freedom and achieved the goal pursued, but there is a moral. Human life is not only for material but obtaining higher ideals and pursuit. Compared with the happiness, morality is a more intrinsic value property of higher education.

\subsubsection{Perfectionism value}

There is a certain degree of drawbacks in both Epistemological value and Tractatus Politicus value of higher education. Contemporary knowledge amounts is increasing with an explosive speed, the space people find knowledge and explore the knowledge has greatly expanded. Under the circumstances, if the promotion of morality level lags behind the growth of knowledge, it is likely to be utilized by some unfair social demands and the goal that use political development to get common social welfare can't be achieved. Scholars, including Brubaker, believe that the development of knowledge should be under the premise of morality, to avoid threating the human society by using knowledge in the wrong way. One view has been widely accepted, that is, scholars should be responsible for the social effect of research contents, at least it should be warned that the study has some negative consequences. Therefore, the Perfectionism value was put forward based on the education cognition value and practical value. The ultimate goal of higher education is not only pursuing knowledge and promoting happiness, but enhancing human society's highest level. The best mentioned here is unable to be verified by the modern science and technology, ethics and philosophy interpretation also has the big difference, but most scholars acknowledge goodness of existence. Scholar Newman believes "Rational perfection is philosophy ", the task of a university is the cultivation of student's intellectual kind, which definite the purpose of university is to strengthen the morality; Hutchins believes the University's goal is to train students to be a real human, "The aim education regress to the life is taking human itself as the goal of education rather than tools, which is different from other education essentially". College education if only pay attention to knowledge and not to the cultivation of virtue, then the society is likely to develop towards a dangerous side, so the development of knowledge should be under the guidance of ethics to promote the healthy development of human society. One of the important tasks at this stage is the formation of a university humanity education model, advertising moral concept and publicity to students, guiding the students and the social development towards perfection. The history of the development of east and west education have stressed the importance of good, such as the ancient Greek liberal education (liberal art education), British gentleman education, Confucian education and quality education and so on. Although there are differences in the way of education and the education content, they both have the same core value, namely liberal education. What is liberal education? This problem goes back to the free condition, that is the relationship between freedom and restriction, the unrestricted freedom is not the real freedom, the freedom is within a certain limit and beyond this limit is chaos. Desire and emotion limit individual actions, if we can't effectively control the desire, we will be controlled by desire. Thus, we can't correctly deal with the relationship with the outside world and society and understand the basic role of social conventions. At this time, freedom is not really free, so analysis from the angle of freedom is just good. Higher education achieve perfection is to promote human liberation and realize all-round development of people.

\section{Conclusion}

The development of contemporary university should not passively accept the transformation of the market economy, but actively pursue individual all-round development to achieve social perfection. The value of the university lies not only in serving for the development of economy and politics, but also providing a progressive concept for historical or social changes to promote the overall well-being of the community. The intrinsic value of the higher education in our country should establish the subject status of perfectionisms and resist unhealthy practices in the context of 
market economy, then guide social development with the value concept of a kind of civilization.

\section{Acknowledgments}

Yan Kui, male, 33 years old, PhD, lecturer, currently in Wuhan University of Technology in the direction of higher education research work, won the Wuhan University of Technology pacesetter honorary title.

\section{References}

[1] Ma Fengqi, Higher Education and Market: Problem and Frame. Higher Education Research, 2009(1):31-41

[2] Sheila Slaughter, Academic Capitalism, The Press of Beijing University, 2008:1

[3] POLANYIK. The Great Transformation: The Political and Economic Origins of Our Time[M].Boston: Beacon Press, 1944: 5-8.

[4] FOURCADE M, HEALY K Moral Views of Market Society. Annual Review of Sociology, 2007,(33):285-311.

[5] Stanford Encyclopedia Philosophy. Intrinsic vs. Extrinsic Value. http:// plato. Stanford. edu /entries /value-intrinsic-extrinsic/. 